\title{
PENGARUH PERILAKU FOLLOWER INVESTOR PADA VOLATILITAS SAHAM
}

\author{
Made Dewi Ayu Untari ${ }^{1}$ \\ ${ }^{1}$ Sekolah Tinggi Manajemen Informatika dan Teknik Komputer, Bali, Indonesia \\ email: ayuntarisakura@yahoo.com
}

\begin{abstract}
ABSTRAK
Penelitian ini bertujuan untuk memperoleh bukti empiris mengenai pengaruh perilaku follower investor pada volatilitas saham dan menganalisis perbedaan perilaku follower investor antara sektor industri penghasil bahan baku, sektor industri manufaktur, dan sektor jasa di Bursa Efek Indonesia (BEI) pada saat terjadi market crashdi Indonesia. Jumlah populasi penelitian sebanyak 507 perusahaan sedangkan jumlah sampel sebanyak 247 perusahaan. Teknik analisis yang digunakan adalahCross-sectional Absolute Deviation (CSAD) untuk mendeteksi perilaku follower investor, uji regresi sederhana untuk menguji pengaruh perilaku follower investor pada volatilitas saham dan uji One Way ANOVA dengan Post Hoc Test dan Least Significant Difference (LSD) untuk menganalisis perbedaan perilaku follower investor antara sektor industri.Hasil analisis menunjukkan bahwa perilaku follower investor berpengaruh positif pada volatilitas saham saat terjadi market crash. Sementara itu, tidak ada perbedaan perilaku follower investor antara sektor industri penghasil bahan baku, sektor industri manufaktur, dan sektor jasa saat market crash.
\end{abstract}

Kata kunci : Perilaku follower investor, volatilitas saham

\section{THE INFLUENCE OF FOLLOWER INVERSTOR BEHAVIOR TO THE STOCK OF VOLATILITY ABSTRACT}

\begin{abstract}
The purposes of this study are to obtain emperical evidence about the influence of followers investor's behaviour to the stock volatility and analyze the difference offollowers investor's betweenindustry sectors producing raw materials, manufacture industry and service industry in the Indonesia Stock Exchange (BEI), during the market crash happened in Indonesia. The population number are 507 companies, while the total sample of 247 companies. Sampling technique used purposive sampling. The analysis technique used was a cross-sectional absolute Deviation (CSADand test One Way ANOVA with Post Hoc Test and Least Significant Difference (LSD. Data shows that the behavior of follower investors has positive effect on the volatility of the current stock market crash occurs. Meanwhile, there was no difference in behavior between the follower investor industrial sectors producing raw materials, the manufacturing sector and the service sector when the market crash.
\end{abstract}

Keywords: Behavior, followers investor, stock volatility

DOI: https://doi.org/10.24843/JIAB.2017.v12.i01.p06

\section{PENDAHULUAN}

Volatilitas saham menunjukkan pergerakan naik turun harga saham akibat tingkat risiko dan return sekuritas yang dihadapi investor pada periode tertentu (Jogiyanto, 2010). Pada masing-masing kondisi pasar di Bursa Efek Indonesia, baik saat bearish dan bullish ditemukan bahwa volatilitas berbeda. Volatilitas mengalami peningkatan saat indeks harga saham gabungan (IHSG) sedang dalam trend menurun, sementara dalam trend menanjak volatilitas bergerak secara stabil. Pada saat bearish ditemukan bahwa terjadipanic selling, sebagaimana yang ditunjukkan dalam penelitian Tim Studi Volatilitas PMIndonesia dan Perekonomian Dunia.

Volatilitas yang tinggi akan meningkatkan kesalahan dalam menentukan harga karena adanya bias dalam mempertimbangkan resiko dan return yang diharapkan (Hwang dan Salmon, 2004). Saat ini ditemukan bahwa keputusan investor lokal dilakukan berdasarkan insting dan tidak jarang beranggapan investor asing mempunyai lebih banyak informasi dibandingkan dengan investor lokal yang bertindak sebagai follower. Sehingga memunculkan dugaan kemungkinan keputusan tidak rasional investor Indonesia dengan berperilaku sebagai follower dapat menggangu volatilitas saham pada pasar modal Indonesia, dengan memperhatikan perkembangan IHSG dan transaksi yang dilakukan investor asing dan lokal selama tahun 2008-2010. Gambar perkembangan IHSG dan transaksi investor asing dan lokal dapat ditunjukkan pada Gambar 1. (Tim Studi Volatilitas PM-Indonesia dan Perekonomian Dunia, 2011). 


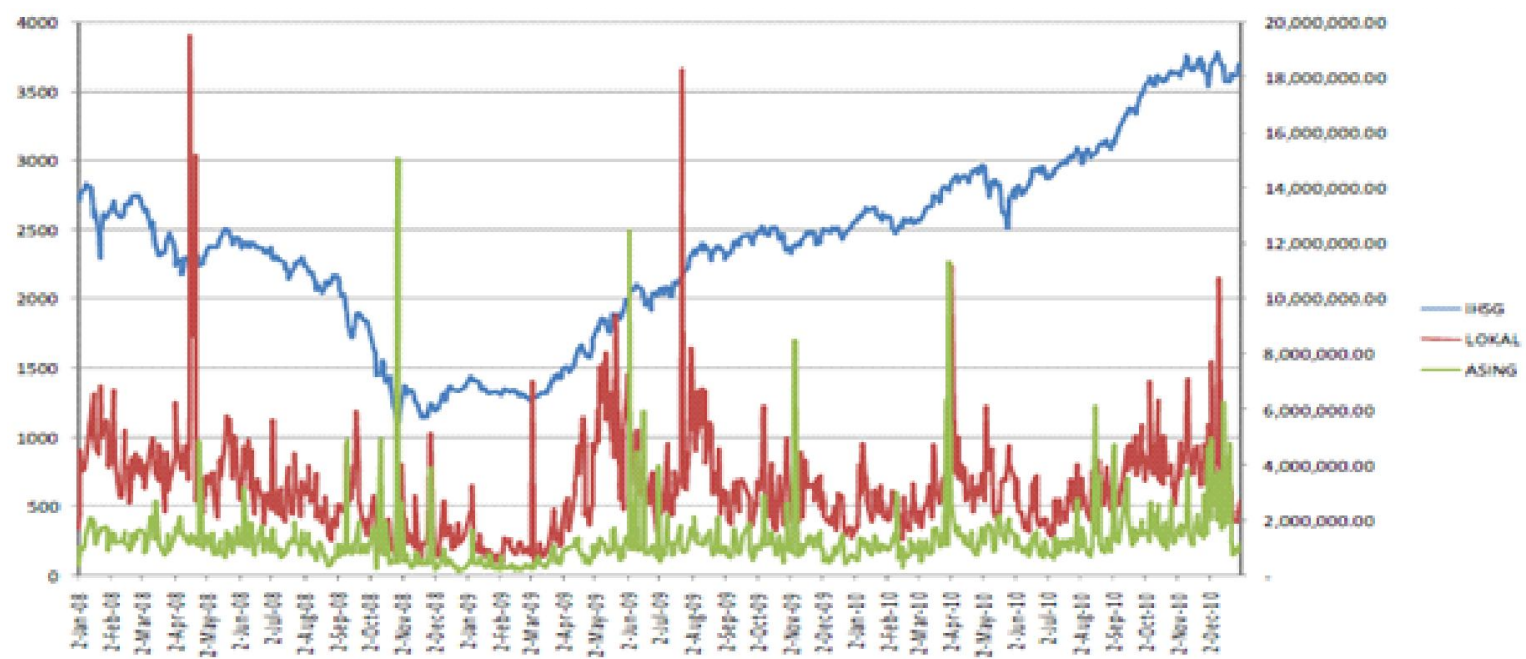

Gambar 1. Perkembangan IHSG dan Transaksi yang dilakukan Investor Asing dan Lokal 2008-2010 Sumber : Tim studi volatilitas pasar modal Indonesia dan perekonomian dunia, 2011

Perkembangan Pasar Modal Indonesia selama 10 tahun kebelakang yaitu tahun 2004-2013 pasar modal Indonesia mengalami 10 kali Market Crash, terkecuali ditahun 2009 tidak terjadi (www. indoalpha.com). Market Crash terjadi karena penyebab yang berbeda-beda, namun penyebab market crash yang tidak pernah berubah adalahakibat emosi perilaku investor yang tidak terkendalikan (www.indoalpha.com). Faktor emosi adalah faktor yang berada di luar asumsi rasional dalam memandang informasi sebagai dasar pengambilan keputusan dalam Teori Hipotesis Pasar Efisien (Fama, 1970). Pengujian tingkat efisiensi pasar modal Indonesia menyebutkan bahwa pasar modal Indonesia berada pada efisiensi bentuk lemah dan tidak menunjukkan bentuk setengah kuat sebagaimana dibuktikan oleh Khajar (2008) dan Dewi dan Artini (2014). Dewi dan Artini (2014) menemukakan beberapa perilaku investor di pasar modal Indonesia yang mengakibatkan efisiensi pasar lemah, yaitu Investor terdiri dari individual-individual yang lugas dan tidak canggih (unsophisticated investors). Untuk pasar yang tidak efisien, investor memiliki pengetahuan yang terbatas di dalam mencermati dan menganalisis informasi yang diperoleh. Dalam Teori Ekspektasi Rasional Investor yang tidak memiliki informasi maka keputusan dalam bertransaksi dilakukan dengan meniru keputusan investor lain yang dirasanya memperoleh informasi lebih banyak (Jogiyanto, 2010).

Penelitian Gunawan dkk., (2011) menemukan bahwa Investor berperilaku rasional pada saat memperoleh return yang tinggi. Sedangkan saat kondisi market crash, investor terlihat berperilaku herding. Ketika kondisi pasar saham sedang jatuh yang memicu terjadinya market crash di pasar modal, maka volatilitas cenderung meningkat. Hal ini berarti, ketika investor semakin banyak menunjukkan perilaku sebagai herding, maka volatilitas cenderung meningkat. Sedangkan ketika kondisi pasar saham meningkat (bullish) maka volatilitas cenderung rendah, dimana pergerakan naik turunnya harga saham lebih rendah dibandingkan ketika kondisi pasar saham sedang turun (bearish).

Widoatmodjo (2010) menemukan bahwa di Pasar Modal Indonesia secara keseluruhan investor lebih cenderung berperilaku tidak rasional daripada rasional. Keputusan investor biasanya berubah secara kontradiktif setelah menerima pengaruh sosial atau orang sekitar (Adhikara, 2008). Dimana seharusnya berdasarkan Teori keuangan tradisional (traditional finance) seperti Teori Hipotesis Pasar Efisien (Fama, 1970) menyebutkan bahwa pelaku pasar selalu berpikir rasional dalam membuat keputusan (Suryawijaya, 2003). Dalam Teori Sinyal investor digambarkan akan menyesuaikan perilakunya sesuai pada pemahaman sinyal yang disampaikan oleh pihak pemilik informasi (Spence, 1973). Investor yang menerima sinyal tidak langsung perusahaan disebut sebagai follower investor (Aprillianto dkk., 2014). Perilaku follower investor yang diproksikan dengan menggunakan deteksi herding behavior menjelaskan disfungsional ekonomi sebagai bias animal spirits untuk menjelaskan perilaku spikologi manusia, seperti naluri dan emosi yang mempengaruhi perilaku manusia. 
Seperti ketidakstabilan karena spekulasi dan ketidakstabilan karena karakteristik sifat manusia yang sebagian besar adalah naluri dasar animal. Konsep herding terbentuk dari pemahaman animal spirit yaitu sekumpulan binatang mengikuti arah yang sama (straight arrows) (Keynes, 1935). Sebuah keyakinan umum menyatakan bahwa perilaku kawanan lazim di pasar saham (Saastamoinen, 2008).

Ketidak rasionalan investor di Indonesia Widoatmodjo (2010) karena pengaruh sosial yang lebih kuat (Adhikara, 2008), sebagai investor pasti akan menggunakan acuan tertentu untuk membeli, menahan atau menjual investasi di pasar modal (salah satunya adalah analisis industri). Analisis industri merupakan salah satu analisis fundamental. Analisis industri mencoba memperbandingkan kinerja dari berbagai industri guna mengetahui jenis industri apa yang memberikan prospek paling menguntungkan atau sebaliknya. Hasil empiris Reilly dan Brown (1997) menyatakan analisis industri itu penting dan perlu dilakukan untuk mengetahui perbedaan kinerja antar industri. Analisi industri membantu investor dan para analis untuk mengidentifikasi peluang-peluang yang menjanjikan atau sebaliknya.Sekar (2006) yang menemukan bahwa profil resiko setiap sektor industri memiliki karakteristik tersendiri sehingga digunakan sebagai pertimbangan investor dalam membuat keputusan investasi. Pengelompokan industri di Bursa Efek Indonesia (BEI) dilakukan berdasarkan standar klasifikasi industri tertentu. Salah satu standar dipakai mengkelompokkan industri di BEI adalah Jakarta Stock Exchange Sectoral Industry Classification (JASICA). Klasifikasi JASICA terdiri dari 3 sektor (serktor utama atau industri penghasil bahan baku, sektor kedua industri pengolahan atau manufaktur, dan sektor ketiga industri jasa) dan 9 divisi yang dikelompokkan menjadi sub industri dan diberi kode dua digit.

Penelitian termotivasi oleh fenomena market crash di pasar modal Indonesia selama tahun 20102013 akibat perilaku tidak rasional investor. Sertaberdasarkan hasil penelitian Gunawan dkk., (2011), Aprillianto dkk., (2014) dan Tim Studi Volatilitas Pasar Modal Indonesia dan Perekonomian Dunia (2011) yang menduga kemungkinan keputusan tidak rasional investor Indonesia dengan berperilaku sebagai follower dapat menggangu volatilitas saham pada pasar modal Indonesia.

Berdasarkan latar belakang, peneliti memiliki pertanyaan yaitu apakah perilaku follower investor berpengaruh pada volatilitas saham di Bursa Efek Indonesia dan apakah terdapat perbedaan perilaku follower investor antara sektor industri penghasil bahan baku, sektor industri manufaktur, dan sektor jasa di Bursa Efek Indonesia (BEI).

Investor yang rasional adalah investor yang cenderung berfikir untuk memaksimalkan kekayaannya dari investasi yang dilakukan. Sehingga dalam hal ini investor akan mencari informasi sebanyak mungkin, seperti informasi laporan keuangan perusahaan, kinerja perusahaan, risiko, keadaan perekonomian,inflasi, suku bunga, dan lainnya yang dijelaskan dalam Teori Hipotesis Pasar Efisien. Sedangkan investor yang tidak rasional adalah investor yang bertindak dengan pertimbangan aspek-aspek non-ekonomi terutama aspek psikologi seperti emosi, subyektivitas, dan berbagai faktor psikologis lainnya yang dijelaskan dalam konsep behavioral finance (Suryawijaya, 2003).

Faktor-faktor yang menyebabkan investor berperilaku tidak rasional dapat diidentifikasi sebagai berikut: a) Faktor psikologis, seperti perilaku overconfidence, optimisme, pesimisme, dan ketakutan akan penyesalan. Investor yang overconfidence dapat meningkatkan volume perdagangan yang diharapkan, meningkatkan kedalam pasar, serta menurunkan utilitas harapan dari investor yang terlalu percaya diri. Investor yang optimisme dan pesimisme menganggap bahwa mereka lebih mungkin mendapatkan kerugian daripada keuntungan dibandingkan orang lain. Keyakinan menyebabkan meningkatkan perdagangan yang didorong oleh sikap optimis investor sedangkan apabila sebaliknya akan menurunkan pergadangan yang didorong oleh sikap pesimis investor. Ketakutan akan penyesalan dapat menyebabkan investor raguragu dan bertindak tidak rasional dalam melakukan investasi (Dhaoui et. al., 2013). b) Dilema tahanan (prisoner dilemma), dimana terjadinya determinasi keputusan transaksi saham. Dalam sebuah keputusan jual beli saham, seorang investor mengalami dilema atas ketidakinginan disebut sebagai "loser" saat melawan arus pasar, sehingga ketika permasalahan yang dihadapi sama, maka harga pasar akan bergerak sesuai dengan hasil keputusan yang ditunjukkan oleh kondisi pasar (Suryawijaya, 2003). c)Perilaku Animal Spirits, mengatakan bahwa terjadinya disfungsional ekonomi dan pasar keuangan adalah karena kegagalan investor untuk mengharapkan pendapatan masa depan secara rasional (Keynes, 1935). Perilaku tidak rasional ini menjadi salah satu penyebab volatilitas saham.

Volatilitas dapat direpresentasikan dengan simpangan baku (standard deviation). Terjadinya volatilitas menunjukkan adanya kecenderungan 
perubahan harga saham. Jika terjadi perubahan harga, maka kemungkinan akan terjadinya pergerakan harga saham yang membentuk pola tertentu tren harga saham (naik atau turun) (Rijanto, 2010). Akerlof dan Shiller (2009) menggantikan bias perilaku investor dengan hipotesis rasionalitas untuk menjelaskan volatilitas saham dan volume perdagangan. Dimana disfungsional ekonomi dan pasar keuangan terjadi karena kegagalan investor untuk mengharapkan pendapatan masa depan secara rasional dan perilaku return saham.

Volatilitas berbeda pada saat pasar sedang dalam keadaan bullish dan bearish. Ketika pasar dalam trendbullish investor puas dengan posisi investasi sebelumnya dan ingin merealisasikan profit (Nastiti dkk., 2012). Hal inilah yang menyebabkan tingginya volatilitas pada saat indeks harga saham bergerak naik tidak terlalu tinggi. Meskipun demikian tidak menutup kemungkinan terjadi transaksi yang besar juga. Sebaliknya jika terjadi trendbearish ketika Investor merasa tidak nyaman dengan investasinya maka mereka akan segera keluar dari pasar dan tidak ada pihak yang ingin mempertahankan harga tersebut. Sehingga, tingkat kecenderungan perilaku kawanan (follower) lebih tinggi pada saat kondisi pasar sedang turun dibandingkan dengan pada saat kondisi pasar sedang naik (Chandra, 2012).

Baddeley et. al., (2012) memperkirakan bahwa ada ukuran yang dapat menyebabkan keputusan keuangan suatu individu akan mengikuti keputusan kawanan. Pada pasar saham Indonesia, indikasi perilaku mengikuti keputusan kawananterlihat pada kondisi panic selling. Sedangkan pada kondisi normal dan imbal hasil yang sangat tinggi, tidak terdapat indikasi perilaku tersebut. Riaz et. al., (2012) yang menguji apakah ada pengaruh faktor psikologi terhadap keputusan investor. Hasil penelitian ini adalah persepsi terhadap risiko sangat berpengaruh dalam membuat keputusan investasi. Penelitian ini menyimpulkan bahwa perilaku investor tergantung pada bagaimana informasi yang tersedia sedang disajikan kepada mereka dan berapa banyak mereka cenderung mengambil risiko sementara membuat keputusan, sehingga memainkan peran penting dalam menentukan gaya investasi dari investor. Model ekspektasi rasional menunjukkan bahwa informed investor dapat meningkatkan profitnya dengan cara memberikan informasi yang tidak akurat untuk menggalang pengikut (follower) dengan tujuan menggerakan harga pasar (Van, 2003).

$\mathrm{H}_{1}$ : Perilaku follower investor berpengaruh positif pada volatilitas saham
Follower investor adalah "penerima sinyal yang tidak langsung dari perusahaan". Terdapat tiga jenis follower investor yaitu follower teman, follower asing, dan follower tren (Aprillianto dkk., 2014). Dewi dan Artini (2014) menemukan beberapa kondisi investor di pasar modal Indonesia yang mengakibatkan lemahnya efisiensi pasar, yaitu Investor terdiri dari individual-individual yang lugas (nä̈ve investors) dan tidak canggih (unsophisticated investors). Menurut Teori Ekspektasi Rasional investor yang tidak memiliki informasi akan melakukan transaksi dengan mengikuti transaksi yang dilakukan oleh investor yang mempunyai informasi (Jogiyanto, 2010). Oleh karena mereka tidak canggih, maka seringkali mereka melakukan keputusan yang salah yang akibatnya sekuritas tersebut dinilai secara tidak tepat, serta seringkali bereaksi berlebihan terhadap suatu perkembangan terbaru (Dewi dan Artini, 2014). Behavioral finance adalah konsep yang memahami dan memprediksi implikasi pasar keuangan yang sistematis dari proses-proses keputusan psikologis (Olsen, 1998). Konsep behavioral finance mengatakan bahwa keputusan investasi yang dilakukan oleh investor lebih banyak dipengaruhi oleh unsur subyektifitas, emosi, dan berbagai faktor psikologis lainnya yang bertentangan dengan asumsi rasionalitas dalam Teori Hipotesis Pasar Efisien (Suryawijaya, 2003).

Shiller (1990) mengungkapkan bahwa antusiasme yang berlebihan memainkan peran dalam memproduksi naik turunnya pasar saham. Sejumlah penelitian telah menganggap perilaku kawanan sebagai penjelasan yang mungkin untuk volatilitas yang berlebihan yang diamati di pasar keuangan seperti penelitian Shiller (1990), dan Cont dan Bouchaud (2000). Pemikiran dibalik pendekatan ini bahwa interaksi pelaku pasar melalui penggiring dapat menyebabkan fluktuasi pasar dalam permintaan agregat, yang menyebabkan banyaknya follower investor dalam distribusi hasil. Dalam literatur efek kerumunan sering dikaitkan dengan fluktuasi besar dalam harga saham (volatilitas) (Xiong, 2012). Berkaitan dengan klasifikasi tiga sektor di Bursa Efek Indonesia (BEI), setiap sektor memiliki karakteristikkarakteristik tersendiri meliputi return dan resikonya (Sekar, 2006).

$\mathrm{H}_{2}$ : Terdapat perbedaan perilaku follower investor antara sektor industri penghasil bahan baku, sektor industri manufaktur, dan sektor jasa.

Gambar 2 menjelaskan konsep penelitian secara sederhana dan menggambarkan secara keseluruhan hipotesis penelitian. 


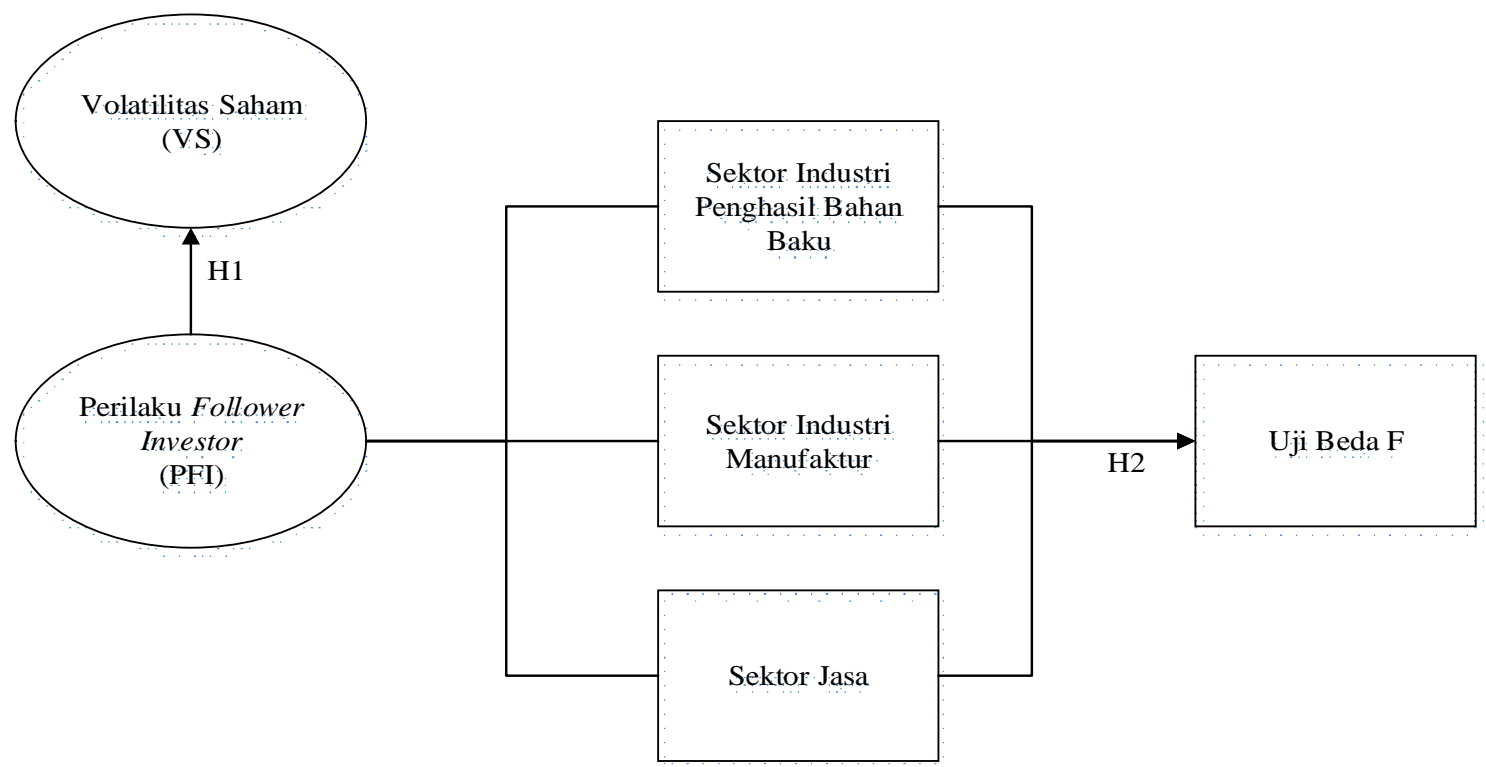

Sumber: Data diolah, 2016

\section{Gambar 2. Model Penelitian}

\section{METODE PENELITIAN}

Penelitian dilakukan pada seluruh perusahaan yang terdaftar di Bursa Efek Indonesia (BEI) selama tahun 2010-2013 pada saat terjadi market crash. Pemilihan sampel menggunakan metode purposive sampling. Kriteria-kriteria yang menjadi pertimbangan dalam penetapan sampel adalah (1) perusahaan yang tergolong kedalam sektor industri penghasil bahan baku, sektor industri manufaktur, dan sektor jasa, (2) perusahaan yang sahamnya terdaftar di Bursa Efek Indonesia (BEI) mulai dari tahun 2009 dan masih terdaftar sampai 31 Desember 2013, (3) perusahaan yang aktif menginformasikan harga saham harian secara konsisten dalam tahun 2009-2013, (4) perusahaan yang menghasilkan nilai koefisien $\gamma_{2}$ yang negatif berdasarkan perhitungan dengan metode pendeteksian perilaku follower investor.

Penelitian menggunakan data sekunder meliputi Laporan keuangan perusahaan yang terdaftar pada Bursa Efek Indonesia periode 2010-2013 dengan mengakses website www.idx.co.id, data harga saham dan daftar indeks harga saham gabungan (IHSG) didapat dari www.finance.yahoo.com.dan penggolongan sektor perusahaan di BEI diperoleh melalui www.ksei.co.id.

Volatilitas saham diukur dengan deviasi standar dari continuosly compound return pada saham. Dalam perhitungan volatilitas digunakan data histori dari harga saham pada interval waktu tahunan sesuai dengan penelitian yang dilakukan oleh Sova (2013).

Volatilitas Saham dihitung dengan rumus sebagai berikut :

$$
s=\sqrt{\frac{1}{n-1} \sum(u i-u)^{2}}
$$

Keterangan:

$\mathrm{S}=$ Deviasi standar

$\mathrm{n}=$ Jumlah titik pengamatan

$u i=$ return saham $\mathrm{i}$

$u$ = rata-rata return

Perilaku follower investor (PFI) adalah perilaku mengikuti keputusan berdasarkan sinyal tidak langsung yang diterima dari perusahaan melalui teman, pihak asing, atau tren sebagai penerima sinyal langsung dari perusahaan (Aprillianto dkk., 2014). Metode yang digunakan untuk mendeteksi perilaku follower investor adalah metode herding behavior oleh Chang et. al., (2000). Pendekatan metode Chang et al. (2000) kuat untuk mendeteksi herding karena menggunakan return equity behavior dengan metode non-linier regression sebagai dasar pengukuran imbal balik equity dengan menggunakan Cross-sectional Absolute Deviation atau (CSAD) dengan rata-rata imbal balik pasar, sebagai berikut.

$$
\operatorname{CSAD}_{t}=\frac{1}{N} \sum_{i=1}^{N}\left|R_{i, t}-R_{m, t}\right|
$$

Keterangan:

$R i, t=$ imbal balik saham individual pada periode $t$

$R m, t=$ imbal balik pasar pada periode $t$

$\mathrm{N}=$ jumlah perusahaan dalam sampel

Kondisi non-linier dari metode ini menggambarkan kondisi dimana investor mengikuti 
konsensus perilaku pasar dan mengabaikan pendapat pribadi mereka (follower investor), sehingga hubungan linier tidak berlaku lagi. Untuk mengetahui apakah terdapat perilaku herding maka dilakukan analisis regresi sebagai berikut:

$C S A D_{t}=\alpha+\gamma_{1}\left|R_{m, t}\right|+\gamma_{2} R_{m, t}^{2}+\varepsilon_{t}$

Keterangan:

$\alpha=$ variabel intersep

$\gamma_{1}=$ koefisien linier antara CSAD dan imbal balik portofolio pasar

$\gamma_{2}=$ koefisien non-linier antara CSAD dan imbal balik portofolio pasar

$R_{m, t}=$ imbal balik portofolio pasar pada periode $t$

$\varepsilon_{\mathrm{t}}=$ standard error

Nilai $R_{m, t}$ diperlukan untuk membandingkan koefisien linier. Jika relatif pada periode pergerakan harga yang besar investor melakukan herding atas dasar rata-rata konsensus pasar, maka hubungan non-linier antara CSAD dan rata-rata imbal balik pasar akan terbentuk. Hubungan non-linier dapat diketahui dari nilai koefisien $\gamma_{2}$ yang negatif dan signifikan secara statistik. Apabila koefisien non-linier $\left(\gamma_{2}\right)$ tidak negatif secara signifikan, CSAD tidak mengalami penurunan pada saat rata-rata pergerakan harga naik maka hasil ini sesuai dengan prediksi rational asset pricing model (Chang et. al.,2000).

Analisis data dilakukan dengan menggunakan regresi linier sederhana yang bertujuan untuk menguji pengaruh perilaku follower investor pada volatilitas saham pada perusahaan yang terdaftar di Bursa Efek Indonesia selama tahun 2010-2013 dan menggunakan uji One Way ANOVAuntuk melihat perbadaan perilaku follower investor antara sektor industri penghasil bahan baku, sektor industri manufaktur, dan sektor jasa di Bursa Efek Indonesia yang diolah dengan program statistical package for science (SPSS).

Model untuk menguji pengaruh perilaku follower investor pada volatilitas saham adalah dengan cara melakukan uji regresi linier sederhana. Berdasarkan uji regresi linier sederhana, pengaruh perilaku follower investor pada volatilitas saham ditunjukkan oleh koefisien $\beta$. Persamaan regresi tersebut adalah sebagai berikut.

$$
\mathrm{VS}=\alpha+\beta(\mathrm{PFI})+\varepsilon .
$$

Keterangan rumus:

VS = Volatilitas Saham, yang diukur dengan Standar Deviasi

$\alpha \quad=$ Konstanta

$\beta=$ Koefisien garis regresi

PFI = Perilaku Follower Investor yang merpakan koefisien non-linier antara CSAD dan imbal balik portofolio pasar

$\varepsilon \quad=$ standard error

Pengujian One Way ANOVA dalam penelitian ini digunakan untuk melihat perbedaan perilaku follower investor antara sektor industri penghasil bahan baku, sektor industri manufaktur, dan sektor jasa. Probabilitas value $\geq$ derajat keyakinan $(0,05)$ maka Ho diterima atau Hi ditolak. Artinya tidak terdapat perbedaan perilaku follower investor antara sektor industri penghasil bahan baku, sektor industri manufaktur, dan sektor jasa. Probabilitas value $\leq$ derajat keyakinan $(0,05)$ maka Ho ditolak dan Hi diterima. Artinya terdapat perbedaan perilaku follower investor antara sektor industri penghasil bahan baku, sektor industri manufaktur, dan sektor jasa.

Pengujian dengan Post Hoc Test / Post Hoc dilakukan dengan Least Significant Difference (LSD) yaitu metode yang digunakan untuk mengetahui variabel dengan perbedaan yang signifikan dan mempunyai asumsi homogenitas varian terpenuhi.

\section{HASIL DAN PEMBAHASAN}

Sampel penelitian terdiri dari 247 perusahaan yang diperoleh dari purposive sampling yang telah ditentukan. Perusahaan yang termasuk Sektor Utama (1) Industri penghasil Bahan Baku terdiri dari 25 perusahaan. Perusahaan yang termasuk Sektor Kedua (2) Industri Manufaktur terdiri dari 81 perusahaan. Perusahaan yang termasuk Sektor Ketiga (3) Jasa terdiri dari 141 perusahaan.

Pengujian kelayakan model menggunakan uji asumsi klasik, yang meliputi uji normalitas data, uji heteroskedastisitas, dan uji autokorelasi. Hasil pengujian asumsi klasik ditunjukkan pada Tabel 1

Tabel 1.

Pengujian Asumsi Klasik

\begin{tabular}{llllc}
\hline No. & $\begin{array}{c}\text { Nama Pengujian Asumsi } \\
\text { Klasik }\end{array}$ & \multicolumn{1}{c}{ Hasil } & & $\begin{array}{c}\text { Keputusan terhadap } \\
\text { Pengujian Asumsi Klasik }\end{array}$ \\
\hline 1. & Uji Normalitas Data & Asymp. Sig. (2-tailed) & 0,200 & Terpenuhi \\
2. & Uji Heteroskedastisitas & Sig. PFI & 0,484 & Terpenuhi \\
3. & Uji Autokorelasi & Lag2 (res_2) & 0,242 & Terpenuhi \\
\hline
\end{tabular}

Sumber: Data diolah, 2016 
Uji normalitas data dilakukan untuk mengetahui data yang digunakan dalam penelitian telah berdistribusi normal atau tidak. Pengujian normalitas data dilakukan dengan menggunakan kolmogorovsmirnov dengan level of significant 0,05. Jika Asymp. Sig. (2-tailed) $>$ tingkat signifikan $(\alpha=0,05)$ maka data dikatakan berdistribusi normal. Berdasarkan Tabel 1dapat diketahui nilai signifikan dengan uji Kolmogorof-Smirnov sebesar 0,200>0,05 maka dapat disimpulkan bahwa model regresi dalam penelitian ini terdistribusi normal.

Pengujian heteroskedastisitas dilakukan dengan menggunakan uji statistik Glejser. Model regresi tidak mengandung adanya heteroskedastisitas apabila nilai signifikansi variabel bebasnya terhadap nilai absolute residual statistik lebih besar dari 0,05. Berdasarkan Tabel 1 dapat diketahui bahwa variabel bebas dalam penelitian ini yaitu PFI memiliki nilai signifikansi 0,484>0,05 maka dapat dikatakan tidak terjadi heteroskedastisitas pada model regresi yang digunakan.
Uji Autokorelasi dilakukan untuk mengetahui ada tidaknya kesalahan penggangu antara variabel pada periode tertentu dengan variabel periode sebelumnya. Untuk mendeteksi adanya data autokorelasi dilakukan dengan uji Langrange Multiplier (LM test), karena sampel dalam penelitian yang digunakan relatif besar yaitu sebanyak 247 observasi. Deteksi Autokorelasi dilihat dari nilai Lag2 (res_2) yang dihasilkan. Jika nilai Lag2 (res_2) lebih besar dari alpha $(\alpha=0,05)$ maka model uji terbebas dari autokorelasi. Berdasarkan Tabel 1diketahui nilai Lag2 (res_2) 0,242 $>0,05$ maka dapat dikatakan tidak terdapat autokorelasi, sehingga model regresi yang dibuat layak digunakan untuk analisis lebih lanjut.

Pengujian hipotesis 1 dilakukan dengan model regresi sederhana, yaitu untuk menguji pengaruh perilaku follower investor terhadap volatilitas saham. Hasil dari regresi sederhana dapat dilihat pada Tabel 2.

Berdasarkan Tabel 2 diketahui bahwa nilai Sig. yang ditunjukkan PFI adalah $0,000<0,05$ sehingga menunjukkan bahwa perilaku follower investor

Tabel 2.

Uji Regresi Linier Sederhana

\begin{tabular}{lrrr}
\hline \multicolumn{1}{c}{ Variabel } & \multicolumn{1}{c}{ Koefisien } & \multicolumn{1}{c}{ T } & sig. \\
\hline Constant $)$ & 0,689 & 30,420 & 0,000 \\
PFI & 1,328 & 15,766 & 0,000 \\
F hitung & 248,579 & & 0,000 \\
R & 0,710 & & \\
Adjusted $R$ Square & 0,504 & & \\
\hline
\end{tabular}

Sumber: Data diolah, 2016

berpengaruh pada volatilitas saham. Dengan melihat persamaan regresi yang dibuat berdasarkan uji regresi sederhana nilai beta koefisien PFI adalah 1,328 sehingga perilaku follower investor berpengaruh positif pada volatilitas saham. Besarnya nilai Adjusted $R$ Square adalah 0,504 yang berarti sebesar 0,504 atau (50,4 persen) variabel terikat yaitu volatilitas saham dipengaruhi oleh variabel bebas yaitu perilaku follow investor. Sedangkan sisanya sebesar 49,6 persen dipengaruhi atau dijelaskan oleh variabel lain yang tidak dimasukkan ke dalam model penelitian.

Pada penelitian ini menemukan bahwa perilaku follower investor berpengaruh positif pada volatilitas saham. Sehingga penelitian ini berhasil menemukan bukti atas dugaan Tim Studi Volatilitas Pasar Modal Indonesia dan Perekonomian Dunia pada tahun 2011, yang menduga kemungkinan keputusan tidak rasional investor Indonesia dengan berperilaku sebagai follower investor (herding) dapat menggangu volatilitas saham pada pasar modal Indonesia.
Sehingga hasil ini dapat membuktikan hasil penelitian Van (2003) dan Gunawan dkk., (2011) dimana berdasarkan model teori ekspektasi rasional menunjukkan bahwa informed investor dapat meningkatkan profitnya dengan cara memberikan informasi yang tidak akurat untuk menggalang pengikut (follower) dengan tujuan menggerakan harga pasar, sehingga tingginya tingkat follower akan meningkatnya fluktuasi pergerakan harga saham atau volatilitas saham.

Hasil penelitian ini menunjukkan bahwa perilaku follower investor terjadi sangat tinggi di Pasar Modal Indonesia pada saat market crash, yaitu dari 350 amatan terdapat 247 amatan yang terindikasi follower. Hasil penelitian ini mendukung dugaan Gunawan dkk., (2011) yang mengindikasikan terjadinya perilaku herding diantara investor pada saat kondisi market crash. Penelitian ini juga menegaskan hasil penelitian Suryawijaya (2003) dan Shiller (1990) yang menunjukkan bahwa investor 
memiliki sifat keserakahan (greed), ketakutan (fear) dan kepanikan (madnes), sehingga karakteristik sifat investor tersebut menjelaskan perilaku individu yang cenderung bergerak atau bertindak sesuai dengan yang mayoritas lakukan.

Penelitian ini juga memberikan tambahan bukti atas hasil penelitian Aprillianto dkk. (2014), yang menduga kuat bahwa investor di Indonesia cenderung ditemukan sebagai follower. Selain itu tingginya tingkat follower berdasarkan hasil penelitian ini, juga dapat membuktikan bahwa investor saat ini cenderung berperilaku tidak rasional sebagaimana yang telah dibuktikan terlebih dahulu oleh Widioatmodja (2010) dan Adhikara (2008), hal ini berarti bahwa minat investor untuk berinvestasi lebih banyak melakukan adopsi meniru.

Pengujian hipotesis kedua dilakukan beberapa tahap. Pengujian yang pertama dilakukan untuk melihat sektor yang memiliki perilaku follower investor tertinggi dan terendah, dengan melakukan pengujian statistik deskriptif pada tiga sektor sampel yang diuji. Hasil pengujian statistik deskriptif ditunjukkan pada Tabel 3.

Tabel 3.

Uji Statistik Deskriptif Perilaku Follower Investor

\begin{tabular}{lccccc}
\hline \multicolumn{1}{c}{ Nama Sektor } & $\mathrm{N}$ & Minimum & Maximum & Mean & Std. Deviation \\
\hline $\begin{array}{l}\text { Sektor Penghasil Bahan } \\
\text { Baku }\end{array}$ & 25 & $-0,393$ & $-0,032$ & $-0,250$ & 0,088 \\
$\begin{array}{l}\text { Sektor Industri } \\
\text { Manufaktur }\end{array}$ & 81 & $-0,445$ & $-0,006$ & $-0,245$ & 0,125 \\
Sektor Jasa & 141 & $-0,503$ & $-0,002$ & $-0,236$ & 0,121 \\
\hline
\end{tabular}

Sumber: Data diolah, 2016

Berdasarkan Tabel 3 nilai tingkat perilaku follower investor tertinggi dan terendah berada pada sektor ketiga yaitu sektor Jasa sebesar - 0,0025 untuk perilaku follower investor tertinggi dan -0,5036 untuk perilaku follower investor terendah. Sedangkan dilihat dari nilai rata-rata, maka tingkat perilaku follower investor paling tinggi terjadi pada sektor kedua yaitu sektor manufaktur sebesar 21,52 persen dan tingkat perilaku follower investor paling rendah terjadi pada sektor utama yaitu sektor industri penghasil bahan baku sebesar 8,86 persen. Uji beda secara serempak dilakukan dengan uji One Way ANOVA (ditunjukkan pada Lampiran uji One Way ANOVA). Berdasarkan nilai Sig. sebesar 0,780 > 0,05 , maka $\mathrm{H0}$ diterima, yang berarti tidak terdapat perbedaan perilaku follower investor antara sektor industri penghasil bahan baku, sektor industri manufaktur, dan sektor jasa.

Uji secara persial dilakukan dengan Post Hoc Test dengan LSD yang ditunjukkan pada Tabel 4.

Tabel 4.

Uji Post Hoc LSD

\begin{tabular}{llcc}
\hline \multicolumn{2}{c}{ Post Hoc LSD } & \\
Perbandingan & Sig. & Mean Difference \\
\hline Sektor Penghasil Bahan Baku & Sektor Industri Manufaktur & 0,867 & $-0,004$ \\
Sektor Industri Manufaktur & Sektor Jasa & 0,572 & $-0,009$ \\
SektorJasa & Sektor Penghasil Bahan Baku & 0,589 & $-0,014$ \\
\hline
\end{tabular}

Sumber: Data diolah, 2016

Hasil Post Hoc Test dengan LSD menunjukkan bahwa tidak terdapat perbedaan perilaku follower investor antara sektor utama yaitu sektor penghasil bahan baku dengan sektor kedua yaitu sektor manufaktur dengan rata-rata perbedaan yang kecil yaitu sebesar-0,0046243 dan secara statistik tidak signifikan $(\mathrm{p}=0,867$ jauh diatas 0,05$)$.
Perbedaan perilaku follower investor antara sektor utama yaitu sektor penghasil bahan baku dengan sektor ketiga yaitu sektor jasa dengan rata-rata perbedaan yang kecil yaitu sebesar $-0,0141188$ dan secara statistik tidak signifikan ( $\mathrm{p}=0,589$ jauh diatas $0,05)$. Perbedaan perilaku follower investor antara Sektor kedua yaitu sektor manufaktur dengan 
sektor ketiga yaitu sektor jasa dengan rata-rata perbedaan yang kecil yaitu sebesar 0,0094945 dan secara statistik tidak signifikan ( $\mathrm{p}=0,572$, diatas 0,05$)$.

Hasil penelitian ini menunjukkan bahwatidak terdapat perbedaan antara perilaku follower investor pada sektor industri penghasil bahan baku, sektor industri manufaktur, dan sektor jasa dengan tingkat rata-rata perbedaan yang sangat kecil. Sehingga hipotesis kedua dalam penelitian ini tidak didukung. Hal ini menunjukkan bahwa sektor industri tidak menjadi dasar pilihan bagi investor untuk melakukan investasi pada saat terjadinya market crash karena investor cenderung berperilaku tidak rasional. Sehingga hasil penelitian ini tidak mendukung hasil penelitian Sekar (2006) yang menemukan bahwa profil resiko setiap sektor industri memiliki karakteristik tersendiri sehingga digunakan sebagai pertimbangan investor dalam membuat keputusan investasi.

\section{SIMPULAN}

Berdasarkan analisis data dan pembahasan yang dilakukan, dapat diambil kesimpulan, perilaku follower investor berpengaruh postif pada volatilitas saham. Tingginya tingkat follower investorkan mengakibatkan volatilitas saham meningkat. Berdasarkan teori sinyal dan teori ekspektasi rasional bahwa informed investor dapat meningkatkan ekspektasinya dengan cara memberikan informasi yang dimiliki, kepada investor lain untuk menggalang pengikut (follower) dengan tujuan menggerakan harga saham. Sehingga pada saat market crash, investor yang panic cenderung bertindak sebagai follower investor. Tingginya tingkat follower investor akan mengakibatkan volatilitas saham meningkat.

Tidak terdapat perbedaan perilaku follower investor diantara sektor industri penghasil bahan baku, sektor industri manufaktur, dan sektor jasa di Pasar Modal Indonesia selama tahun 2010-2013. Hasil penelitian ini memberikan bukti baru bahwa karakteristik dari masing-masing sektor industri tidak menjadi dasar pilihan bagi investor untuk melakukan pilihan investasi ketika investor berperilaku tidak rasional sebagai follower investor atauketika terjadi market crash.

Penelitian ini hanya dilakukan pada saat terjadinya market crash di Pasar Modal Indonesia, sehingga penelitian ini tidak dapat membandingkan tingkat volatilitas saham pada saat pasar dalam kondisi normal dengan pasar pada saat kondisi crash. Penelitian ini hanya melihat perilaku follower investor secara umum, sehingga tidak dapat melakukan perbandingan perilaku follower investor yang lebih beragam.Penelitian selanjutnya dapat memperluas amatan dengan membandingkan volatilitas saham pada saat kondisi pasar normal dan saat kondisi pasar crash. Penelitian selanjutnya diharapkan dapat menggolongkan perilaku follower investor berdasarkan follower teman, follower asing, dan follower tren.

\section{REFERENSI}

Adhikara, M.F. Arrozi. (2008). Mental Accounting Investor di Bursa Efek Indonesia. Jurnal Ekonomi Universitas Esa Unggul, 13(2).

Aprillianto, Bayu., Novi Wulandari, \& Taufik Kurrohman. (2014). Perilaku Investor Saham Individual dalam Pengambilan Keputusan Investasi: Studi Hermeneutika-Kritis. E-Journal Ekonomi Bisnis dan Akuntansi, 1(1), 16-31.

Akerlof, A. George, \& Shiller, J. Robert. (2009). Animal Spirits How Human Psycology Drives the Economy and Why It Matters for Global Capitalism. Princeton University Press.

Baddeley, M., C. Burke, W., Schultz, \& P. Tobler. (2012). Herding in Financial Behaviour: A Behavioural and Neuroeconomic Analysis of Individual Differences.

Chang EC, Cheng J. W., \& Khorana A. (2000). An examination of herd behavior in equity markets: an international perspective. Journal of Banking and Finance, 24, 1651-1679.

Chandra, Maximilian. (2012). Pengukuran dan Analisis Perilaku Herding Pada Saham IPO Bursa Efek Indonesia Tahun 2007-2011. Tesis. Universitas Indonesia.

Cont, R., \& Bouchaud, J. Philipe. (2000). Herd Behavior and Aggregate Fluctuations in Financial Markets. Journal of Macroeconomic Dynamis, 4, 170-196.

Dewi, Luh Putu Kartika dan Artini, Luh Gede Sri. 2014. Pengujian Efisiensi Pasar Bentuk Setengah Kuat di Bursa Efek Indonesia.Ejurnal Manajemen Universitas Udayana, 3 (12).

Dhaoui, Abderrazak et al. (2013). The Impact of Investor Psychology on Stock Market: Evidence From France. Journal of Academic Researh in Economics, 5(1).

Fama, Eugene F. (1970). Efficient Capital Markets: A Review of Theory and Empirical Work. The Journal of Finance, 25(2), 383-417. 
Gunawan, Hari Wijayanto, Noer Azam Achsani, dan La Ode Abdul Rahman. 2011. Pendeteksi Perilaku Herding pada Pasar Saham Indonesia dan Asia Pasifik. Forum Statistika dan Komputas, 16-23.

Hwang, Soosung, \& Salmon, Mark. (2004). Market Stress and Herding. Journal of Empirical Finance, 11, 585-161.

Jogiyanto, Hartono. (2010). Teori Portofolio dan Analisis Investasi. Edisi Ketujuh. Yogyakarta: BPFE-YOGYAKARTA.

Khajar, Ibnu. (2008). Pengujian Efisiensi dan Peningkatan Efisiensi Bentuk Lemah Bursa Efek Indonesia pada saat dan sesudah Krisis Moneter pada Saham-Saham LQ-45. National Conference on Management Research.

Keynes, J. Maynard. (1935). The General Theory of Employment Interest and Money.

Nastiti, Ayu, \& Suharsono Agus. (2012). Analisis Volatilitas Saham Perusahaan Go Public dengan Metode ARCH-GARCH. Jurnal Sains dan Seni ITS, 1(1).

Olsen, A. Robert. (1998). Behavioral Finance and Its Implications For Stock-Price Volatility. Financial Analysts Journal, 54(2), 10-18.

Reilly, F.K., \& Keith C.Brown. (1997). Investment Analysis and Portofolio Management. 5 th Ed. Massachusetts: Adison-Wesley Educational Publisher Inc.

Riaz, L., Al Hunjra, \& Rauf I. Azam. (2012). Impact of Psychological Factors on Investment Decision Making Mediating by Risk Perception: A Conceptual Study. Middle East Journal of Scientific Research, 789-795.

Rijanto, Y. Arief. (2010). Dampak Rumor Terhadap Volatilitas Harga Saham. Jurnal Manajemen Bisnis, 3, 261-285.
Saastamoinen, Jani. (2008). Quantile Resression Analysis of Dispersion of stock returnsevidence of herding?

Sekar, M. Rayun. (2006). Perbedaan Pengaruh Inflasi, Tingkat Suku Bunga dan Nilai Tukar Rupiah/US Dollar Terhadap Return Saham (Studi Pada Saham Properti dan Manufaktur).

Shiller, Robert J. (1990). Market Volatility and Investor Behavior. The American Economic Review. 80(2), 58-62.

Suryawijaya, A. Marwan. (2003). Ketidakrasionalan Investor di Pasar Modal. Pidato Pengukuhan Jabatan Guru Besar pada Fakultas Ekonomi Universitas Gadjah Mada. Yogyakarta.

Spence, M. (1973). Job Market Signaling. The Quarterly Journal of Economics, 87(3), 355-374.

Sova, Maya. (2013). Pengaruh Ratio Leverage Terhadap Volatilitas Saham Pada Industri Barang Konsumsi di Bursa Efek Indonesia Tahun 2004-2008. E-Journal WIDYA Ekonomika, 1 .

Tim Studi Volatilitas Pasar Modal Indonesia dan Perekonomian Dunia. 2011. Volatilitas Pasar Modal Indonesia dan Perekonomian Dunia. Jakarta: Bapepam-LK.

Van, Bommel Jos. (2003). Rumors. The Journal of finance, 58(4).

Widoatmodjo, Sawidji. (2010). Irasionalitas Investor dan Potensi Krisis Ekonomi. Simposium Riset Ekonomi IV.

Xiong, James X. (2012). The Chinese Art Market and the Originof Bubbles. Morningstar Municipal Research.www.indoalpha.com. URL:http://www.indoalpha.com/anatomymarket-crashes/ (Diakses pada 16 Mei 2015, jam 14.00) 